\title{
Master of Education
}

National Cancer Institute

\section{Source}

National Cancer Institute. Master of Education. NCI Thesaurus. Code C71369.

A master's degree in education awarded after the completion of a program of one to three years in duration. This acknowledgment comprises about 4-6 years of university study in total and is a degree conferred by American and Canadian institutions for educators moving on in their field. 